Article

\title{
Steered by Numbers: How Quantification Differentiates the Reform of a German University
}

\author{
Michael Huber \\ Department of Sociology, Bielefeld University, 33615 Bielefeld, Germany; E-Mail: michael.huber@uni-bielefeld.de
}

Submitted: 29 October 2019 | Accepted: 31 December 2019 | Published: 9 April 2020

\begin{abstract}
Quantification theories assume that numbers govern and steer a policy field or an organisation. In order to steer successfully, however, the local interpretation of numbers takes centre stage as the meaning of numbers-and thus the way how actors respond to them-varies between systems or sectors. Empirically, this article reviews how a German university makes sense of political numbers and their implicit steering signals, and how quantification alters its organisational structures and reshapes the roles of academics. The article analyses the translation process distinguishing between three levels: the political discourse on university reform; the organisational adaptations; and the effects they have on the professional academic role. The article finds that the university has highly differentiated strategies to respond to the 'governance by numbers,' and that it has established independent number-based steering systems. We also find that such differentiation of programmes makes the university management more flexible, helping it deal with anticipated goal conflicts and unwanted allocative effects, but it also places serious strain on-and potentially overburns-the coordination provided by the university's central administration. We also find that academics have started to align their behavioural strategies towards fulfilling their organisational goals and that they tend to deviate from professional expectations. Discussing these differentiated strategies, this article shows how the differentiation of governance approaches also contributes to the university becoming an 'organisational actor.' These preliminary findings suggest the need for and potential direction of further investigations.
\end{abstract}

\section{Keywords}

organizational reform; quantification; university management; university studies

\section{Issue}

This article is part of the issue "Quantifying Higher Education: Governing Universities and Academics by Numbers" edited by Maarten Hillebrandt (University of Helsinki, Finland) and Michael Huber (University of Bielefeld, Germany).

(C) 2020 by the author; licensee Cogitatio (Lisbon, Portugal). This article is licensed under a Creative Commons Attribution 4.0 International License (CC BY).

\section{Introduction}

For the past 40 years, higher education studies have become acutely aware of and have criticized, the various changes and reforms in the sector. In this context, the new public management (NPM) provided the main analytical lens through which reform was perceived and practical tools to overcome the diagnosed inefficiencies, opacity, and professional idiosyncrasies of the higher education sector were chosen (for NPM see Hood, 1991). Over the years, conceptual and practical innovations have been added, suggesting that reforms do not form part of a grand plan, but recurrently intervene to repair the shortcomings and unintended effects of pre- vious interventions (on this general feature of reform see Luhmann, 1992, p. 74). Wittrock summarises this layering nicely: "Universities exist with layer upon layer of quite divergent legacies, yet somehow they have also succeeded in preserving a strong element of continuity amidst all the change" (Wittrock, 1993, p. 305). The most current layer of university reform is 'quantification,' which means that numbers are behind identification and adoption of promising strategies, permit the 'objective' observation of the effects of reforms, and ensure accountability. This 'governance by numbers' (e.g., Miller, 2001; Rose, 1991) is expected to rationalise and modernise the university, and-for example through mechanisms of rankings (see Ringel, Brankovic, \& Werron, 
2020) - the entire higher education sector. However, the main assumption of this article that this rationalisation process does not come without costs; it not only restructures the university but also reshapes the university's relation to its environment, i.e., politics and staff members.

In the theoretical narrative of this new layer, the effectiveness of numbers is taken for granted while the documented experience with the numerical steering of organisations, and more specifically, universities, is at best ambivalent. One widely communicated reason refers to the resistance of the university to any change; in particular, the German university has a longstanding reputation of being unable and unwilling to reform (e.g., Stichweh, 1994). Another, methodological reason, which the wider public are often concerned with, relates to the accurate measurement of professional performance. This article explores how governance by numbers actually occurs, if or to what extent universities live up to the implicit promise of quantification's effectiveness, and, most importantly, this article asks how numbers restructure the organisation.

The argument is outlined in three sections. First, the quantification literature is reviewed in order to show how numbers can improve steering. As far as 'governance by numbers' is concerned, Miller and O'Leary's (1994a, 1994b) account of the reform at Caterpillar in the 1980s is used as an analytical frame for the empirical exploration of the numerical reform of universities. Examining the effects of numbers on organizational reform, the authors suggested to not focus on the organisation alone, but to include the societal or political discourse as well as to reflect on the alterations at a personal level. Thus, Miller and O'Leary's blueprint allows us to describe university reform by discerning three intertwined analytical levels: First, the political programme promoting generic ideas about the need, and main direction, of reform. Second, the organisational level, where these programmes are enforced by changes to the production process and the reallocation of responsibilities. At a third, individual level, the workers are assigned new responsibilities and skills for the production process. Numbers imply that workers need to develop numeracy, i.e., the skill to understand and apply numbers. This layered model has been created for a singlecase study and used to develop a broader understanding of reforming economic firms through numbers. This article explores the process of quantifying the performance of universities and compares how quantification reshapes the 'production processes' of a German university. This exploratory study leads to a set of tentative questions that should help to design further systematic research.

\section{Quantification and Organisation}

This section is divided into three subsections: First, we briefly sketch a communicative perspective on quantification; second, we outline the basic argument of the
Caterpillar study by Miller and O'Leary. Together these considerations allow us to, third, delineate a framework that structures the empirical investigation of Section 3.

\subsection{Quantification and Organisational Change}

Even at the turn of the last century, Weber (1978) already considered accounting and control through numbers to be a decisive step in the development towards the modern capitalist society. The broader social phenomena we subsume under the notion of quantification, however, have long been ignored by the social sciences (overview in Miller, 2007). This neglect was turned into awareness only over the last two decades when numbers were identified as critical for modernity (prominently, Porter, 1996) and the establishment of state organisations (e.g., Heintz, 2012). Increasingly, numbers are identified as a ubiquitous phenomenon (Mennicken \& Espeland, 2019). As a result of this growing interest, quantification studies provide a wide, internally highly differentiated and specialised research area (overview in Heintz, 2018). This converges in the broad definition that quantification comprises "the production and communication of numbers-and its consequences" (Espeland \& Stevens, 2008, p. 402). Such a communicative approach to quantification is anticipated by systems' theory, as Luhmann (1997) had already suggested before the excitement over quantification, that numbers simplify communication as they insulate the respective statement against criticism; in other words, arguments sustained by numbers are more difficult to negate than others (see also Heintz, 2016). This basic idea also serves as a starting point for the debate on quantification by Espeland and Stevens (2008). These authors, however, further develop the basic communicative model of quantification with the help of the theory of speech-acts by John Austin (1975), and discern different types of numbers and how numbers may improve and rationalise governance. Assuming that different things are done by different numbers (Espeland \& Stevens, 2008, p. 405), the main focus of Espeland and Stevens is on the varied consequences of quantification, i.e., how new categories of countable things emerge, how numbers and their implicit accuracy can be interpreted, and where and when new infrastructures of counting materialise. One aspect of Espeland and Stevens's diversity-of-numbers argument that's of particular interest to this article concerns the contextualised meaning of numbers. For example, when universities use publication scores to document scholarly productivity (see Krüger, 2020), these scores assume a different meaning when they are applied, e.g., by funders to benchmark resource allocation. The effects of this differentiation of meanings are also investigated by Power (2007). He proposes a 'sequential hypothesis' about the changing meaning of numbers: Numbers are first generated at the operational level to make performance tangible and visible for management. These numbers 'turnthe-inside-out,' providing evidence of the organisational 
performance from the perspective of operators. Once these numbers are released into the public realm, they can be used at will, for example, to promote externali.e., mainly political or economic-interests, and then be redirected to the operational level. This 'turning-theoutside-in' may challenge the local (often professional) performance routines. These effects of quantification on higher education have, for example, been studied in Espeland and Sauder's (2007) seminal article on reactivity. Their study suggests that the university management responds to results of rankings by improving their performance but also by gaming those numbers in order to climb up the ranks. As far as the active steering of organisations through numbers is concerned, the practice should, generally speaking, rationalise management and unburden the bureaucratic authority as "members are provided with information, which, when previously programmed benchmarks are met, triggers decisions" (Luhmann, 1964, p. 98, author's translation). Empirical studies on the effects of numbers on universities suggest this automated steering is not without collateral effects (e.g., Huber \& Hillebrandt, 2019).

The basic argument is that numbers call for interpretation (or translation) at the point of use, otherwise their unfiltered application may be incomprehensible to the addressees. Thus, the general promise of a communication-based concept of quantification is to efficiently implement reform strategies, albeit at the cost of altering the organisation, its perception of external (and internal) demands, as well as its decision-making procedures. This article explores the specific forms and empirical variations in performance indicator communication within a German university-Middletown University (MU). This article uses Miller and O'Leary's (1994a, 1994b) analysis of the reform of the Caterpillar plant in Decatur, Illinois, as its analytical framework which is discussed in the next section.

\subsection{The Caterpillar Story: An Analytical Framework}

In the early 1980s, the Caterpillar company, which designs, develops, and produces machinery and engines, failed to compete successfully with its Japanese competitor Komatsu. Miller and O'Leary (1994a, 1994b) analysed Caterpillar's recovery and showed that the process of making the company profitable again started at the political level. The political discourse perceived Caterpillar and its problems as part of a broader challenge to the American industrial sector, its competitiveness, and more generally to American prosperity itself. The modernisation and reform of US industries in general, and of Caterpillar in particular, called for plant re-design and re-training of the workforce; its main objective was, from a political perspective, the re-establishment of American competitiveness. Although not all voices in the political discourse agreed on every aspect of how the American industry should recover, they all converged on the 'need to act.'
Against this political background, the Caterpillar company re-structured and modernised its plants. Miller and O'Leary focus their studies on the plant in Decatur, Illinois, where two dimensions of organizational adaptation caught their attention: First, the production process was re-organised through a new assembly line that simplified and modularised the production process - the authors also refer to "cellular working arrangements" (Miller \& O'Leary, 1994b, p. 480). The second dimension concerns the establishment of a quantitative 'audit trail' for all aspects of the production process enabling continuous comparison with the Japanese competitor through numbers; this "competitor benchmarking" is a:

Calculative practice that the image of Japanese competition was made real to those working in the North American plants of Caterpillar Inc. By this means, 'competitiveness' was no longer an abstract idea, a simple invocation to work harder, to do more, to produce quicker. 'Competitiveness' meant 'personto-person' competition with a Japanese worker. The "threat" from Japan to American manufacturing was to be given a face, and a number. (Miller \& O'Leary, 1994b, p. 472, author's emphasis)

This practice enabled the comparison of all activities within the plant, between plants, and their competitors. This comprehensive comparability also changed the expectations of the skills of the workforce. Benchmarking forced Caterpillar to re-educate its workforce as ittogether with the modularised production structureestablished "a new way of relating individuals to their work within the factory" (Miller \& O'Leary, 1994b, p. 477). Workers had to develop numeracy, i.e., the continuous comparison with the competitor's performance required them to learn how to read numbers and then to have the flexibly to adapt their work to diverse benchmarks. At this individual level, quantification established an 'economic citizenship' that not only empowered workers but also placed new responsibility on their shoulders, and thus altered their traditional membership role (Miller \& O'Leary, 1994b, p. 478). Miller and O'Leary (1994b, p. 473) notice that the workforce obtains a new, more influential role, as:

Authority would flow directly from the customer to the work process, along the Assembly Highway, in accordance with the ideal of empowered workers responding immediately to the wants and wishes of the customer. Authority would no longer be embodied in the character of the supervisor, or in the routine calculations of a technique such as standard costing, but would inhere in the process itself.

As mentioned above, Luhmann (1964, p. 98) suggested that quantification unburdens the management. Miller and O'Leary confirm this assumption and add that the burden is internally re-arranged and, in large parts, 
shifted to the workforce. These changes, however, do not establish a stable structure. Instead, Miller and O'Leary (1994b) emphasise the instability of the new configuration of the production process:

A perpetually failing series of programs and instruments for governing economic life. It is this instability, combined with a constant search for temporary stabilities, that in large part explains the process of trying to create a new reality on the factory floor in a particular North American factory in the 1980s. (p. 491, author's italics)

Instability, and, in response to it, the continual repair of failures, is seen as a critical part of the success of Caterpillar's reform as it established a permanent adaptation process. The organisation, staff, and politics were kept alert at all times.

\subsection{Guidelines of Empirical Exploration}

Miller and O'Leary's (1994a, 1994b) layered model of organisational change provides us with a basic understanding of reform that suggests, first, a distinction between three levels, i.e., politics, organisation, and individuals. Reflecting on the interactions of these three levels is expected to more comprehensively capture the drivers of, and challenges to, reform. Second, the reorganisation of the working procedures draws particular attention to the receiving side of knock-on effects, i.e., the workers and their skills to handle quantification and to assume new responsibilities are considered important although they are often overlooked in the literature. Third, the instability of reform is considered essential for its success, i.e., success is based on establishing what we described as a continual process of repairing the flaws of the previous reform (see also Luhmann, 1992). These basic elements of an analytical framework guide the empirical analysis of the next section.

\section{The Case of a German University and Its Reform}

This study follows the single-case-scheme outlined above. Thus, the results of the empirical part are tentative and exploratory, focusing on the effects of quantification at the successful, medium-sized MU in Germany. The MU lacks a medical department and instead has developed a strong social science focus. Such deviation from the 'normal university' requires more managerial effort by the MU-management as the state-programmes discussed below are designed to steer a comprehensive, 'normal' institution. The study is based on policy documents and interviews. References to MU-documents and interviews have been anonymised and the cited passages from the interviews were translated by the author. At the core of the article, an interview with the team of the Vice Chancellor's office, including the Vice Chancellor, is analysed sequentially (e.g., Herz, Peters, \& Truschkat,
2015); it explores what specific solutions to the problem of quantification and reform can be identified at MU. The focus on one university clearly suggests that the main results of this article cannot be 'representative.' At best, it is able to identify critical issues which could inform and further guide more systematic investigations into the relationship between quantification and organisational reform across German universities.

\subsection{The Political Side of the University Reform}

In the early 1990s, the political debate surrounding German higher education emphasised the urgency of university reform. The reform needed to respond to three principal challenges. First, the need for the regime to be more efficient in order to provide reasonably priced higher education for as many people as possible. Second, the once internationally leading German university system had become a laggard in global competition, failing to innovate and thus endangering the prosperity of German society. A third challenge concerned the academic profession. The professional opacity turned decision making into a 'garbage can' (Cohen, March, \& Olsen, 1972), it protected "rotten apples" within the academic profession and avoided to hold professionals accountable for the substantial resources used in the higher education sector (for the German case see e.g., Schimank, 2005). Political discourse at the time highlighted the need for change; the NPM-doctrines were expected to provide the tools necessary to improve the efficiency and accountability of universities and consequently reshape the welfare and competitive functions of the higher education sector.

However, the German reform discourse takes us a step further as it converges at the assessment that the university is unable (and often unwilling) to reform itself. Thus, reform has to be driven externally, by the state (Stichweh, 1994). The traditional state-dependency of the German universities (see also Clark, 1986) could be identified in the interviews. The interviewees addressed the state and its reform objective right at the beginning of the conversation and summarised the basic reform idea: "Achievements should be rewarded, that was the key motto of the Lander Parliament" (interview).

This ambition to reward achievement suggests the introduction of differentiation in resource allocation to benefit those who perform better. The way this differentiation is implemented requires more concrete steps of operationalisation. One important step was shown at the beginning of one of the interviews, when the interviewers briefly introduced the comparative research project. One interviewee reacted to this methodological remark by reporting that $\mathrm{MU}$ was placed in a setting where all universities of the land were being compared according to performance indicators (see in next paragraph Leistungsorientierte Mittelverteilung, in short LOM). The state administration had delineated a comparative environment in which the reform unfolded. The state de- 
fined the objects of comparison (universities) and the criteria of comparison (indicators), and together they indicate where and how much differentiation is in political demand (for these critical elements of comparison, see Heintz, 2016).

The state administration designed the LOM (i.e., 'performance-based budgeting'; for more detail, see Huber \& Hillebrandt, 2019) which condenses the state's ideas regarding how and where the universities should compete. The LOM operationalises academic performance through publication scores, third party funding, and 'status'-indicators. While all of the academic activities are measured, the interviews emphasised that only a small part of the state's monetary allocations is used for such competitive arrangements. Within the cameralistic budgeting, LOM is therefore biased and relative. Biased, as LOM weighs performance uniformly across the sector and fails to account for differences, for instance, among the size of universities or disciplinary characteristics. For example, MU can be expected to have a weaker performance in publications and third-party funding as it lacks a medical department that normally performs well on these indicators. The university may counteract this bias by adapting and optimising the measurement methods, but a bias towards natural and life sciences, as well as bigger units, affects financial distributions. LOM is relative as resource allocation is restricted to single accounts of the cameralistic model, not the overall budget. This implies that the resource pool does not increase with increased productivity, but (if at all) as the result of political decisions. Therefore, redistributions by LOM do not reflect improvements in productivity, but the relative increase vis-à-vis other universities. In effect, one could get less money for higher productivity if other universities had increased their productivity to a greater degree. As a result, the LOM challenges planning at the organisational level (a repeated complaint throughout the interviews) as it does not address the immediate performers but affects the university as a whole. Another effect of this comparative setting is that the university has become the key object of comparison. In the higher education studies, this shift has been captured by the university "becoming an organisational actor" (e.g., Krücken \& Meier, 2006). Practically, this means that the university administration is held responsible for the performance of its staff and the optimal positioning of the university in the LOM scheme. Control of performance is shifted towards the university. Besides LOM, the state also installed other programmes where additional resources are allocated. The interviewees mentioned that the state compensates for: (i) tuition fees; (ii) negotiates performances directly with the university management (for example, student uptake); (iii) adds overhead resources to third-party funding; and (iv) allocates resources directly to chairs or faculties. All these programmes are initiated by politics (see also Hillebrandt, 2020). They are fragmented and vary greatly in terms of objectives and allocative procedures, but their common feature is the idea of rewarding achievement through differential allocation.

The state imposes governance by numbers and the university steers some of these programmes with the help of their own numbers. For example, tuition fees were highly contested in Germany, and after 2013 all Lander administrations retreated from this idea and provided free higher education again. Given that fees transformed the income structure of universities, the state substituted the fees, however not as part of the overall budget, but as an isolated, publicly visible provision to accentuate students as an income source of universities. These direct allocations are based on an undifferentiated headcount but are turned into a performance-driven regime inside the university. Another state-programme directly allocates funding based on agreements with institutes or persons as direct service providers for the state; here experiments regarding student access issues, specific educational programmes, or expertise are initiated and supported through additional financial allocations. These allocations are partially driven by indicators but depend mainly on the task at hand. To some extent, they can be connected to quantification, but this connection is mainly made by the selection of providers. The next section outlines how the university 'internalises' these state-programmes.

\subsection{How the MU Adapts the Political Reform}

The state plays a critical role in university reform and uses quantification to operationalise some individual programmes. Major parts of the implementation of these programmes, however, are delegated to the university. This division of labour is recognised by MU and seen as being a part of the reform process: "Actually, prospective management is all the Land is providing, it is up to us to provide the rest. And universities handle it differently" (interview, author's emphasis).

Thus, the university's actorhood manifests itself in MU's new responsibility for performance and its translation of these 'state numbers' into locally meaningful and applicable strategies and indicator systems. The remainder of this section illustrates some examples of how this has been done at MU.

The Caterpillar model suggested that work processes need to be modularised, simplified, and restructured. But to internalise competition, Caterpillar not only restructured the process but also made its elements easy for the workers to compare through 'competitor benchmarking.' The MU case suggests a different development as the main source of change is not the organisation but the state-LOM and its predefined competitive environment. The MU mirrored and slightly adapted the LOM by making subtle changes. First, the university scheme changed the relative weight of LOM-indicators. Second, although most indicators are standardised across the sector-e.g., number of publications, student/teacher ratios, graduates, and third-party funding-local and po- 
litical indicators such as 'gender equality' were added. Third, algorithms like the averaging the outcome over three years or installing caps to the possible changes of resource allocations were applied to ensure a robust, manageable outcome. The university scheme deviated from the LOM and the interviews highlighted that the university's foremost interest was not competition, but to guarantee a manageable allocation of resources. As far as the production process is concerned, the performance indicators address the Chair, i.e., the professor and her (academic and non-academic) collaborators, as the main production unit. At first sight, this arrangement seems unspectacular, but it gets more interesting when compared to other allocation strategies.

Student fees provide a different example of organisational adaptation. As mentioned above, all Lander parliaments ceased to demand fees from students after 2013. To substitute these payments, the state compensated a certain amount per student, i.e., it focused on the receiver of performance, and treated all students equally. At the university level, the management of student fees was translated into a very different idea that altered the production process and, in the course of the reform, established a new 'performance address.' The organisational strategy also started with the number of students but allocated their fees per 'full-time student equivalent' (Vollzeitstudienäquivalent, VSÄ), i.e., an indicator reflecting the relative share that teachers and teaching groups have in the education of each single student. Thus, the university shifted the focus onto the performance of teachers. The VSÄ reflects that students are not taught by one, but by several teachers, all of whom should get a fair share of the fee. Thus, the VSÄ places performance at the (aggregated) level of the module (and exams), as this is considered the fairest representation of teaching performance. Manageability is now considered to depend on internal fairness, otherwise 'system maximisers' could exploit the system and generate additional managerial challenges (for more, see Section 3.3). Thus, MU-teachers connected by the modules received their 'payment' relative to their share of each module; internally, all teachers linked to a specific module got an equal share of the fee. From an organisational perspective, membership of such professional groups became critical. An interviewee remarked on the previous situation:

We had no legally responsible units in the departments. Professional groups were informal, nobody could determine who really belongs to them. Because, if somebody would say, I have got nothing to do with your professional group, I set up my own, nobody could have objected. (interview)

With the fees, the professional groups became the new addressees. They were easily rearranged and at least partially able to overcome the problems of internal redistribution in departments which were described as follows: "We had the experience that individual units, teaching units, allocate very different burdens....Single staff members supervised 30-40 diplomas, and one staff supervised one per term and refused to accept a second supervision" (interview). Thus, the use of VSÄ helped to: (i) translate the state programme to the organisational level; and (ii) to provide a solution to the management problem of distributive fairness (rather than, as above, efficiency).

These two cases suggest that political programmes are adopted and administered by the university one by one, i.e., the production process is modified not in a comprehensive way, but each political initiative remains isolated also at the university level. Three aspects are particularly interesting: First, the organisational autonomy is reinforced by the university's management of the inherent tensions between the political programmes, their underlying objectives, and their locally feasible implementation. Second, the university is able to provide more efficiency, effectiveness, and fairness at the same time, just not within the same programme. This increase in differentiation, that was claimed by organisational sociology (e.g., Luhmann, 1964), requires the strengthening of the organisational core. This effect can also be observed when the university launched its own 'special support programme' that aimed to (moderately) fence off the effects of political programmes and help staff to obtain funds-for example, by covering travel costs or the support of publications-which would otherwise slip between the cracks in other allocative mechanisms. This 'special support programme' is a way in which the organisation can individually manage unwanted but politically intended effects of the overall allocation regimes that interfere with the normal operations of the university. Third, the university applied these political strategies independent of each other, not because they were not able to bundle them, but because the political origin of these programmes required both public visibility (cf. Luhmann, 1981) and the decoupling of programmes. This last also enabled the university to respond more flexibly and to compensate some of the organisationally dysfunctional effects of other programmes. The university reform can be best illustrated as a grid, with three horizontal layers of politics, organisation, and staff, each re-organised distinctly by the vertical programmes, mostly initiated by the state (see Table 1). While a unifying strategy had been chosen at Caterpillar, the MU kept those political strategies loosely coupled, and 'invented' a variety of performance addresses: Individuals and Chairs, professional groups, and organisational substructure, such as institutes or departments, were to be held responsible for performance. This new flexibility in allocating responsibilities also enabled new management options: For example, when modules became the key addressees for performance, the university was able to (and in some cases, does) reorganise its study programmes by rearranging modules without considering disciplinary structures. The university is able to gen- 
Table 1. Summarising the main features of the MU reform.

\begin{tabular}{lllll}
\hline & & \multicolumn{2}{c}{ Three Levels of Analysis } \\
\hline & & $\begin{array}{l}\text { Political } \\
\text { expectations }\end{array}$ & $\begin{array}{l}\text { Organisational } \\
\text { adaptation }\end{array}$ & $\begin{array}{l}\text { Setting up responsible } \\
\text { workers }\end{array}$ \\
$\begin{array}{l}\text { How MU responds } \\
\begin{array}{l}\text { to political } \\
\text { programmes }\end{array}\end{array}$ & $\begin{array}{l}\text { Performance } \\
\text { agreements }\end{array}$ & Direct demands & $\begin{array}{l}\text { Facilitator, pure } \\
\text { administration }\end{array}$ & $\begin{array}{l}\text { Department, institute, } \\
\text { Chair }\end{array}$ \\
& LOM & Reward as principle & $\begin{array}{l}\text { Optimise Universities } \\
\text { performance }\end{array}$ & Chairs are held responsible \\
& Student funding & Substitute student \\
& fees & $\begin{array}{l}\text { VSÄ as internal allocative } \\
\text { mechanism }\end{array}$ & $\begin{array}{l}\text { Professional groups around } \\
\text { module }\end{array}$ \\
& $\begin{array}{l}\text { Special support } \\
\text { programmes }\end{array}$ & - & $\begin{array}{l}\text { Negotiated balance } \\
\text { and peace }\end{array}$ & Individual Researcher \\
\hline
\end{tabular}

erate numerous (interdisciplinary) degree courses from a small number of modules.

\subsection{New Professional Roles}

Quantification, i.e., the allocative procedures, together with the adaptations of the production process, demands the individual member to perform flexibly, cooperate with changing module partners, and behave entrepreneurially (also vis-à-vis the university administration, e.g., Scholz \& Stein, 2010). Our interviewees, however, did not praise this new flexibility and adaptability of the academic profession, but rather emphasised that individual professors overreacted to numbers, and gamed them. For example, the interviewees were puzzled by the fact that performance indicators had such a strong steering effect given that they only covered an insignificant part of the budget. They explained this effect by the psychological disposition of professors. The examples they referred to in the course of the interview ranged from a professor 'freaking out' because he 'lost' $€ 12$, to staff systematically manipulating their performance measurements, for example by slicing one exam into three (thus, tripling their internal LOM score), or using ISBN for teaching slides and counting them as publications. These complaints suggest that professors responding disproportionally to changes in allocation are 'system optimisers' and are considered morally deficient. An 'economic' explanation would point to the fact that even the smallest differentiation in allocation may establish new social positions derived from the 'demonstrative consumption' that is made possible by these additional resources and reshape professorial behaviour (e.g., Veblen, 2009). This economic explanation can be supported by organisational studies that perceive the apparent overreaction as a reasoned response when repeated decisions of performance-based budgeting stress how critical those indicators are for their success in the organisation. By these decisions, the academic teachers arerepeatedly-differentiated as either successful/affluent members of the profession or less successful/poor ones, and they learn that even subtle differences highlight the different levels of appreciation by the organisational management, and therefore provide strong incentives for them to change their behaviour (see also Luhmann, 1981, p. 96). Thus, what the university management perceives an overreaction reflects the emergence of new organisational and political norms. Overreaction is not a personal deficiency, but rather signals the presence of tensions regarding the professional understanding of roles and the organisation. Given that only a small number of professionals overreacted, it might be concluded that the majority are well integrated into the new regime. A "new academic citizenship" emerged which strongly responds to organisational signals and the competitive structures of the regime (see also Scholz \& Stein, 2010).

\section{Analysis and Concluding Remarks}

Although this section must start by cautioning against generalising our findings as they are based on a single case, it is also true that the layered model of Miller and O'Leary proved helpful for structuring and explaining the performance-oriented reforms at $\mathrm{MU}$, and thus turned Caterpillar and the MU into comparable cases. With the university case also showing that organisational reform is not driven by organisational dynamics alone but is complemented and sometimes contradicted by political programmes, and the necessary re-socialisation of university members (see also Schiebel, 2019), the results of this study seem to have the potential to inform more comprehensive future studies in the field of higher education.

A first finding that could guide such studies confirms that politics played a critical role for the reforms. However, the MU case differs from Caterpillar as politics not only emphasised the urgency of reform but was also a critical source of change. The state introduced the idea of 'rewarding performance' in the form of performance indicators to differentiate the allocation of resources. Due to its restricted volume however, the LOM did not 
fundamentally redirect the university's financial governance, rather, it operated on a symbolic level, but was nevertheless effective. This restricted change indicates the key challenge to the university management: On one hand, it takes up new responsibilities and redesigns the production process; and on the other hand, it perpetuates the university's state-dependency and its professional traditions (see Brunsson \& Sahlin-Andersson, 2000). This trade-off has penetrated the very core of the reform and leaves the university with the herculean task of 'changing without change.' Politics agreed on the need to act and provided a set of programmes. However, related changes-for functionality reasons-cannot be translated directly to the university level but are partially absorbed by the organisation. The questions that follow from this observation concern the degree to which political changes reach the organisational level, if they can remain purely symbolic or to what extent do they redefine the functionality of the university?

A second finding concerns the organisational responses to resource differentiation. The performanceindicator-based strategies were-as the communication theory of quantification suggested-translated by the university into local schemes. To meet organisational needs, the MU modified performance indicators to 'correct' the effects of the LOM that were found to be counterproductive. A comparative view would enlighten us about the structural limits to such translations. As organisational sociology predicted, the diverse state programmes will lead to an internal differentiation of organisational management. The fact that the state's programmes were not bundled at the organisational level but implemented independently, can partly be explained by a political logic of visibility, but also by the fact that isolated ways to 'digest' the political strategies strengthen the organisational core and thus the MU's actorhood. The political programmes are compartmentalised by the university, not necessarily to ease or optimise the production process, but to reflect on the overall organisational purpose, management demands, and coordination problems (cf. Luhmann, 1964, p. 144). A strong indicator of this reclaimed autonomy of the administrative core is the special programme that should repair allocative unfairness. At the same time, such compartmentalisation provided operational flexibility and allowed the university to navigate the conflict between goals-e.g., between efficiency and fairness-and as a result, contributed to the new actorhood of the university. But this actorhood develops under conditions of state-dependency and raises the question of how far such independence is politically or organisationally feasible. This becomes tangible when contrasting the variance of political programmes and the organisational response with Caterpillar's uniform approach to simplify and modularise the production process. Some of the local solutions indicate the emergence of a strong bureaucracy. Also, the case of substituting student fees points to the strengthening of managerial functions, and it also provides the university with the possibility of flexibly combining modules and thus establishing new courses and study programmes at low cost. The production process may be simplified at the level of the individual programmes as, overall, the reform generated a confusing multitude of new addresses and competing procedures. This variety of new institutional addresses made the reform process less stable and, at the same time, allowed the university management to balance unwanted effects and reduce the biases implicit in the strategies.

Third, the organisational reform challenges traditional responsibilities and by that also the traditional roles of academic professionals. Caterpillar needed to generate a workforce that was able to read and willing to be guided by numbers; staff who should 'own' the production process. The higher education literature indicates that professions are already 'owners' of the production process and that they could (until now) resist organisational attempts to appropriate teaching and research. This assumption made the observation of the uncertainties of professorial behaviour even more interesting. The challenges to professional roles have internally been interpreted as individual and highly irritating strategies; 'system optimisers' and their 'morally deficient behaviour' indicated that new allocation strategies tend to trigger the optimisation of income rather than of output or professional quality. However, the staff's deviant behaviour showed that the new governance rules had started to have an effect, even if the university management apparently would have preferred less adaptation. The balance between steering effects and professional independence needs to be reassigned, mainly for the purpose of university management. How this could be done should be studied in greater detail.

The MU case confirms the importance of quantification for university reform, but also raises numerous new questions that require more comprehensive studies. For example, the interviewees suggested that the translation of political programmes varies by university. If the state programmes were dealt with independently, these specific local solutions would require further, comparative attention. Moreover, organisational sociology suggests that the political expectations would lead to internal differentiation and a strengthening of the central administration. Does this assumption hold for all political programmes and organisations equally or do we observe a more centralised, bundled steering of financial allocations? Furthermore, if the professional role changes, what would it mean for the profession of academics? Are professionals able to deal with the various demands that each translation process brings about or do professional roles diversify and further specialise? Also, up to what point can the professional core of the university be adapted and when does change challenge the functioning of the university?

This article placed itself between two positions characteristic of higher education studies. On one hand, a vast literature has emerged discussing the deficiencies 
of universities which can be healed only by 'turning the university into an organisational actor' (e.g., Krücken \& Meier, 2006), while on the other hand, the particularity of the university is highlighted (e.g., Musselin, 2007). This study emphasised the flexibility of the organisational form of the university and its ability to make trade-offs between the necessary adaptation to financial and political conditions of research and teaching, and its academic, professional core. Although this seems difficult at times, the management of and through numbers by the MU may serve as a reminder of the inevitability of the universities having to protect professionals against political, economic, or public interventions, and of the assurance that it can to a large extent be incorporated into the traditional organisational form of the university.

\section{Acknowledgments}

I gratefully acknowledge funding by the Deutsche Forschungsgemeinschaft (DFG) (Project No. 627097) under the Open Research Area Scheme (Project Title: QUAD-Quantification, Administrative Capacity and Democracy). The article has greatly benefited from the discussion with workshop participants and the anonymous reviewers.

\section{Conflict of Interests}

The author declares no conflict of interests.

\section{References}

Austin, J. (1975). How to do things with words. Cambridge, MA: Harvard University Press.

Brunsson, N., \& Sahlin-Andersson, K. (2000). Constructing organizations: The example of public sector reform. Organization Studies, 21(4), 721-746

Clark, B. (1986). The higher education system: Academic organization in cross-national perspective. Berkeley, CA: University of California Press.

Cohen, M., March, J., \& Olsen, J. (1972). A garbage can model of organizational choice. Administrative Science Quarterly, 17(1), 1-25.

Espeland, W., \& Sauder, M. (2007). Rankings and reactivity: How public measures recreate social worlds. American Journal of Sociology, 113(1), 1-40.

Espeland, W., \& Stevens, M. (2008). The sociology of quantification. European Journal of Sociology, 49(3), 401-436.

Heintz, B. (2012). Welterzeugung durch Zahlen: Modelle politischer Differenzierung in internationalen Statistiken, 1948-2010 [Generating the world through numbers: Models of political differentiation in international statistics, 1948-2010]. Soziale Systeme, 18(1/2), 7-39.

Heintz, B. (2016). „Wir leben im Zeitalter der Vergleichung." Perspektiven einer Soziologie des Vergleichs ["We live in an era of comparison." Perspectives of a sociology of comparison]. Zeitschrift für Soziologie, 45(5), 305-323.

Heintz, B. (2018). Von der Allmacht der Zahlen und der Allgegenwart des Bewertens [About the omnipotence of numbers and the omnipresence of assessments]. Soziologische Revue, 41(4), 629-642.

Herz, A., Peters, L., \& Truschkat, I. (2015). How to do qualitative structural analysis: The qualitative interpretation of network maps and narrative interviews. Forum Qualitative Sozialforschung/Forum: Qualitative Social Research, 16(1). http://dx.doi.org/10.17169/ fqs-16.1.2092

Hillebrandt, M. (2020). Keeping one's shiny Mercedes in the garage: Why higher education quantification never really took off in Germany. Politics and Governance, 8(2), 48-57.

Hood, C. (1991). A public management for all seasons? Public Administration, 69(1), 3-19.

Huber, M., \& Hillebrandt, M. (2019). "Pay for promise" in higher education: The influence of NPM on resource allocation in German universities. Historical Social Research, 44(2), 247-269.

Krücken, G., \& Meier, F. (2006). Turning the university into an organizational actor. In G. S. Drori, J. W. Meyer, \& H. Hwang (Eds.), Globalization and organization: World society and organizational change (pp. 241-257). Oxford: Oxford University Press.

Krüger, A. K. (2020). Quantification 2.0? Bibliometric infrastructures in academic evaluation. Politics and Governance, 8(2), 58-67.

Luhmann, N. (1964). Funktionen und Folgen formaler Organisation [Functions and consequences of formal organisations]. Berlin: Duncker \& Humblot.

Luhmann, N. (1981). Politische Theorie im Wohlfahrtsstaat [Political theory in the welfare state]. Munich: Günter Olzog Verlag.

Luhmann, N. (1992). Zwei Quellen der Bürokratisierung in Hochschulen [Two sources of bureaucratization in universities]. In A. Kieserling (Ed.), Universität als Milieu [University as ambience] (pp. 74-79). Bielefeld: Haux.

Luhmann, N. (1997). Die Gesellschaft der Gesellschaft [The society of society]. Frankfurt: Suhrkamp.

Mennicken, A., \& Espeland, W. (2019). What's new with numbers? Sociological approaches to the study of quantification. Annual Review of Sociology, 45, 223-245.

Miller, P. (2001). Governing by numbers: Why calculative practices matter. Social Research, 68(2), 379-396.

Miller, P. (2007). Wie und warum das Rechnungswesen in der Soziologie in Vergessenheit geriet [How and why sociology forgot accounting]. In A. Mennicken \& H. Vollmer (Eds.), Zahlenwerk: Kalkulation, Organisation und Gesellschaft [Creating numbers: Calculation, organization and society] (pp. 19-42). Wiesbaden: VS Verlag.

Miller, P., \& O'Leary, T. (1994a). Accounting, "economic citizenship" and the spatial reordering of manufac- 
ture. Accounting, Organizations and Society, 19(1), 15-43.

Miller, P., \& O'Leary, T. (1994b). The factory as laboratory. Science in Context, 7(3), 469-496.

Musselin, C. (2007). Are universities specific organizations? In G. Krücken, A. Kosmützky, \& M. Torka (Eds.), Towards a multiversity? Universities between global trends and national traditions (pp. 63-86). Bielefeld: Transcript.

Porter, T. (1996). Trust in numbers: The pursuit of objectivity in science and public life. Princeton, NJ: Princeton University Press.

Power, M. (2007). Organized uncertainty: Designing a world of risk management. Oxford: Oxford University Press.

Ringel, L., Brankovic, J., \& Werron, T. (2020). The organizational engine of rankings: Connecting "new" and "old" institutionalism. Politics and Governance, 8(2), 36-47.

Rose, N. (1991). Governing by numbers: Figuring out democracy. Accounting, Organizations and Society, 16(7), 673-692.

Schiebel, F. (2019). Entscheidungsprobleme in Universitäten [Decision problems at Universities] (Unpub- lished Masters dissertation). Bielefeld University, Bielefeld, Germany.

Schimank, U. (2005). 'New public management' and the academic profession: Reflections on the German situation. Minerva, 43(4), 361-376.

Scholz, C., \& Stein, V. (2010). Bilder von Universitäten-Ein transaktionsanalytisch-agenturtheoretischer Ansatz [Images of universities-A transaction-cost analytical, agency theoretical approach]. Betriebswirtschaftliche Forschung und Praxis, 62(2), 129-149.

Stichweh, R. (1994). Die Form der Universität [The form of the university]. In R. Stichweh (Ed.), Wissenschaft, Universität, Professionen [Science, university, professions] (pp. 246-277). Frankfurt: Suhrkamp.

Veblen, T. (2009). The theory of leisure class. Oxford: Oxford University Press.

Weber, M. (1978). Economy and society: An outline of interpretive sociology. Berkeley, CA: University of California Press.

Wittrock, B. (1993). The modern university: The three transformations. In S. Rothblatt \& B. Wittrock (Eds.), The European and American university since 1800: Historical and sociological essays (pp. 303-362). Cambridge: Cambridge University Press.

\section{About the Author}

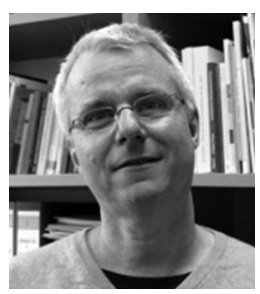

Michael Huber is Professor of Sociology at the Department of Sociology at Bielefeld University. His research is focused on organisational sociology, higher education studies, and regulatory policymaking, more specifically, risk-based regulation. 